\title{
Fallen Woman Further (Re)Framed: Jewels and Travels, Tragedies and Secrets, Judge Jean Hortense Norris
}

Mae C. Quinn ${ }^{*}$

I. INTRODUCTION

On May 8, 1899, Abraham and Straus ran an advertisement in the Brooklyn Daily Eagle declaring "women of Brooklyn have learned to look for . . larger opportunities." It promised their "expectations, no matter how great, are always realized" by purchasing sale items at their department store. " "Women's Shirt Waists," known as a modern clothing option for working-class women at the time, were offered as "Unusually Strong Values" that day. ${ }^{3}$

The trendy button-ups were seen as more liberating than tighter-fitting bodice-blouses of the 1800s; could be worn day or night; straddled the line between masculine and feminine; and cleverly morphed in appearance over the years to track fashion trends. ${ }^{4}$ The popularity of the garments also led indirectly to a rise in feminism in New York City. In 1911, a fire swept through the Triangle Waist Company factory in the East Village, where the shirts were manufactured. ${ }^{5}$ The blaze killed nearly 150 seamstresses working in unsafe conditions, some of whom fell from the factory's

* (C) 2018 Mae C. Quinn, Visiting Professor of Law, University of Florida School of Law. Thanks to my Research Assistant Joshua Lopes and the outstanding student editors at the Kansas Law Review.

1. Advertisement, Abraham and Straus: Continuing Our May Sale of Muslin Underwear, BROOK. DAILY EAGLe, May 8, 1899, at 8.

2. Id.

3. Id.

4. Shirtwaist, ENCYC. FASHION, http://www.fashionencyclopedia.com/fashion_costume_culture/M odern-World-1900-1918/Shirtwaist.html [https://perma.cc/A692-72GU] (last visited Oct. 1, 2019) ("[T]he shirtwaist was a liberating item of clothing. It took the place of the stiff, tight, high-collared bodices of the nineteenth century. By the early 1910s cotton shirtwaists were worn by hundreds of thousands of working women. Through the decade the garment changed according to fashion trends. Early shirtwaists featured pleats in the shoulders .... By 1914 shirtwaists had less rigid puff shoulders and often were worn untucked so that some fabric flowed below the natural waist. That look later made way for the dropped-waist dresses of the 1920s.").

5. Peter Dreier \& Donald Cohen, The Fire Last Time, New RePuBlic (Mar. 11, 2011), https:// newrepublic.com/article/85134/wisconsin-unions-walker-triangle-shirtwaist-fire [https://perma.cc/43 X6-9M7L]. 
windows while trying to save themselves. ${ }^{6}$ The tragedy inspired women of all walks of life to come together and fight to protect their sisters from treacherous professional hazards. ${ }^{7}$

But, on the evening of May 8, 1899, after Mrs. Jean Hortense Norris's husband died in their small flat on Lafayette Avenue in Brooklyn, ${ }^{8}$ it is unclear how concerned she was with larger opportunities, great expectations, strong values, feminism, or a profession. She was just twenty years old. ${ }^{9}$ Neighbors likely wondered whether Norris-an unusually young widow-would recover from her fall.

Thus, it may have seemed unlikely when about a decade later Mrs. Jean Hortense Norris - who continued using her married name - managed to graduate from New York University Law School to become one of the city's first women lawyers and a leader in feminist legal activities, including representing defendants accused of prostitution in New York City's Women's Court. ${ }^{10}$ It may have been even more astonishing that ten years after joining the bar she was named New York's first woman judge, appointed to serve in the same Women's Court where she previously defended alleged wayward women. ${ }^{11}$ And they may have become most shocked of all when, a decade after that, she was the focus of a high-profile investigation for unfair treatment of the accused sex workers before her, leading to what has been described as another downfall-her public removal from the bench in 1931 for being "unfit."12 Or, perhaps these things did not surprise those closest to her at all.

Until recently, few knew the story of Jean Hortense Norris, her life, lawyering, and judicial role adjudicating cases of alleged "fallen women."

6. Id.

7. Id.

8. The Revolver Was Loaded, BROOK. DAILY EAGLE, May 9, 1899, at 16.

9. As will be further discussed, infra, like so many things about Norris's life, even her birth date is open to contest. $I d$. (stating that Norris was twenty at the time of her husband's death). See also Thyra Espenscheid, She Wanted to Be a Circus Rider, but Became a Judge, BrooK. DAILY EAgLE, Sept. 7, 1924, at 3 (stating that Norris was twenty-two at the time of her husband's death); Liberal Faces Ouster Move, GETTYSBURG TIMES, June 11, 1931, at 10 ("About 24 years ago she found herself widowed at the age of 22.").

10. Liberal Faces Ouster Move, supra note 9, at 10 (noting that Norris graduated from New York University in 1911 and labeling her a "leader of the feminists"); Marion Weston Cottle, Women in the Legal Profession, 4 Women LAW. J. 60, 60 (1915) (naming Norris as one of the volunteer defenders for the Women's Court).

11. Mae C. Quinn, Fallen Woman (Re)framed: Judge Jean Hortense Norris, New York City 1912-1955, 67 U. KAN. L. REV. 451, 476-77 (2019) [hereinafter Quinn, Fallen Woman (Re)framed)] (discussing Norris's tenure on the bench); see also Jean H. Norris, Judging Women, 48 WOMAN's HOME COMPANION 23, 23 (1921).

12. Quinn, Fallen Woman (Re)framed, supra note 11, at 492-508 (discussing Samuel Seabury's allegations and investigations); see also First Woman Judge in New York is Found Unfit, BiNGHAMTON PRESS \& SUN Bull., June 25, 1931, at 1. 
Previous scholarship largely focused on her alleged misconduct as a jurist and official fall from grace. ${ }^{13}$ My prior Kansas Law Review article, Fallen Woman (Re)Framed, sought to surface and document more about Jean Hortense Norris - including details about her work as one of this country's first practicing women attorneys and actions as a feminist legal activist even from the bench. ${ }^{14}$

Fallen Woman (Re)framed also more carefully examined Norris's misconduct prosecution led by legal legend, retired-judge, Samuel Seabury. ${ }^{15}$ It considered the unique features of Norris's judicial "fitness" inquiry, the process that was afforded, and the weight of the evidence presented during the proceedings. ${ }^{16}$ In this way, it offered a re-hearing of sorts, providing a more complete picture of Norris beyond a shamed and disrobed judge - while providing one of the only historical legal assessments of Seabury as one of the first "special counsel" appointed in this country. In the end it suggested Seabury's work and investigation should not necessarily be seen as a model. ${ }^{17}$ Rather, the Seabury Commission proceedings, while historic, must also be seen as somewhat arbitrary.

This said, as noted in that work, its more holistic telling was not intended to absolutely absolve Norris as a jurist. ${ }^{18}$ Rather, it promised future presentation of at least some additional facts about the judge and her life-including evidence that Seabury and his staff apparently did not investigate or introduce. This essay offers that expanded record. Exploring two different avenues of investigation that were overlooked by Seabury's formal proceedings — or any other it seems - as postscript, this additional account may raise more questions than it answers.

\section{JEWELS AND TRAVELS}

Samuel Seabury's evidence against Judge Jean Norris showed that she did things that — even if not proven to be intentional wrongdoings — - raised

13. See, e.g., Cheryl D. Hicks, TALK With You Like a Woman: African AMERiCAN Women, JuSTICE, AND REFORM IN NEW YORK, 1890-1935, at 179-80 (Thadious M. Davis \& Mary Kelly eds., 2010); Burton W. PeretTi, NightClub City: Politics AND AMuSEMENT IN MANHATTAN 127-28 (2007). But see Elizabeth IsRaels Perry, After the Vote: Feminist Politics in LaGuardia's NEW YORK 119-21 (2019). Perry's work relies in part on this author's research and was published posthumously earlier this year. It also provides a more fulsome and nuanced account of Jean Hortense Norris as lawyer and judge, with particular focus on Norris as a political figure. See generally id. The details of this essay extend beyond that treatment.

14. Quinn, Fallen Woman (Re)framed, supra note 11, at 471-92.

15. Id. at $492-508$.

16. Id.

17. Id. at 496-503.

18. Id. at $453-54$. 
questions about her moral compass, self-interest, and consistency in feminist commitments. ${ }^{19}$ And as suggested by Cheryl Hicks, Norris surely seemed willing to turn a blind-eye to racial discrimination and corruption unfolding all around her. ${ }^{20}$ More than this, if Seabury dug deeper, he may have uncovered additional details about Norris warranting further inquiry about possible improper financial dealings.

First, Norris never did account for the funds she used to pay a private African-American probation officer in the Magistrates' Court. ${ }^{21}$ As I have written elsewhere, private funding of public court functions became the focus of official inquiry once Anna Moscowitz Kross was appointed to the Women's Court bench in $1934 .^{22}$ And it is possible that, even if rooted in an effort to improve services for the Black community, monies received to support the position were given to Norris in exchange for some kind of official favor.

Second, although it does not appear to have been discovered or publicly discussed by Seabury, it seems quite possible that Norris was also receiving gifts and quid pro quo support. Like Mayor Jimmy Walker, she enjoyed numerous extravagant vacations that did not entirely comport with her reported income, busy court schedule, or standard responsibilities as a sitting judge. ${ }^{23}$ The press generally covered these extended trips as referenda on Norris's international reputation, and Norris herself framed them as opportunities to study criminal law in action abroad. ${ }^{24}$ But given their frequency, duration, likely cost, and other circumstances, they raise serious questions that might have been worthy of further exploration by Seabury at the time.

On January 24, 1923, after her first ten-year reappointment to the bench, Norris was one of only about 150 passengers on the Cunard Lines

19. Id. at 496-508.

20. See HiCKS, supra note 13, at 179-80 (noting that Judge Norris rendered unlawful sentences in sixteen cases involving African-American women and held a "mistaken perception that the black community neglected its young women").

21. See Paul Harrison, Woman is Needed to Study into Characters of Woman, Magistrate Norris Claims, ElmiRA STAR-GAZETTE, Feb. 26, 1931, at 8 ("For 18 months she paid a Negro investigator, and finally persuaded Negro societies to assume the obligation.").

22. See generally Mae C. Quinn, "Feminizing" Courts: Lay Volunteers and the Integration of Social Work in Progressive Reform, in FEMINIST LEgAL HISTORY: ESSAYS ON WOMEN AND LAW (Tracy A. Thomas \& Tracey Jean Boisseau eds., 2011).

23. See Seven Years of Ragtime Featured Career of Mayor Walker at City Hall, BROOK. DAILY EAGLE, Sept. 2, 1932, at 6 (reporting on the numerous trips taken by Mayor Walker during his tenure, which became part of the focus of Seabury's inquiry); Corruption: A Woman's Turn, TIME, Feb. 23, 1931 (reporting in 1931 that Norris made \$7,000 a year).

24. Mrs. Warner Heads Zonta, Binghamton PreSs \& Sun-Bull., Apr. 12, 1927, at 13 (listing the places Norris visited and served on the International Mixed Court). 
cruise ship, SS Samaria, ${ }^{25}$ as it set sail from New York harbor on a 33,000 mile "tour of the world." 26 Advertised as an "epic holiday of luxury, wonder and leisure," and lasting "over four months," the "cruise de luxe" covered the seven seas and visited numerous ports along the way. ${ }^{27}$ Indeed, when Norris applied in December 1922 for a new passport for purposes of the trip, she indicated she would be gone for up to five months to visit "Gibraltar, Italy, Egypt, Portugal, China, Japan, and Hong Kong.,"28 Although the New York Times reported on Norris being among the lucky guests who got to enjoy amenities such as horseback riding, it made no mention of any official reason for Norris's trip. ${ }^{29}$ Nor did she list one on her passport application. ${ }^{30}$

Interestingly, however, once Norris was at sea the City apparently put out a press release announcing she was traveling to the far east at the request of Chief Magistrate McAdoo to study the treatment of women offenders abroad, as well as drug trafficking. ${ }^{31}$ Picked up by small papers outside of New York City, such as the Pittsburgh Daily Headlight (Kansas) and Buffalo Courier, the announcement made sure to note that while she was making the trip at the request of McAdoo she would be expected to pay for the trip out of her own pocket. ${ }^{32}$

In contrast, once the Samaria arrived to Hawaii in May, newspapers there reported Norris was "combining business and pleasure" in healthy doses. ${ }^{33}$ Although she claimed to be studying "[j]udicial procedure all around the world," the reporter noted, Norris "frankly, doesn't seem like a judge at all save for a certain directness of speech and a straightforward way of surveying her interlocutor." 34 It also listed other prominent "joyriders de luxe" on the trip, including wealthy financiers, insurance executives, business owners, and even a baroness who were able to enjoy

25. Manifest Documents, Samaria Cruise Ship (May 31, 1923) (on file with author).

26. Samaria Off Today on Tour of World, N.Y. TIMES, Jan. 24, 1923, at 10 [hereinafter Samaria Off Today]; see also Advertisement, Thos. Cook \& Son: Around the World, N.Y. Herald, Apr. 27, 1922, at 21 [hereinafter Around the World].

27. Around the World, supra note 26, at 21.

28. See U.S. Passport Application, Jean H. Norris (Dec. 27, 1922) [hereinafter 1922 Passport Application] (on file with author).

29. See Samaria Off Today, supra note 26, at 10.

30. See 1922 Passport Application, supra note 28 (listing "travel" as the reason for her trip around the world).

31. See, e.g., Woman Judge to Study Methods of Oriental Justice, PitT. Daily Headlight (Kan.), Feb. 12, 1923, at 3; Woman Judge to Study Oriental Way of Justice, BuFf. CourIER, Feb. 8, 1923, at 5 .

32. See Woman Judge to Study Oriental Way of Justice, supra note 31, at 5.

33. See Woman Jurist is Girdling Globe to Study Courts, HonOlulu StAR-Bull., May 7, 1923, at 4 .

34. Id. 
alcoholic beverages on the ship, which were permitted despite prohibition in the United States. ${ }^{35}$

Met by the press upon her return to New York City, Norris claimed she had convened conversations with women's groups across the world, served as a guest jurist in multiple countries, and promised to produce a written report of her "investigation" and official findings for Chief Magistrate McAdoo's benefit. ${ }^{36}$ But it seems that report was never written or presented to the press. And Norris took several more international cruises over the next seven years before she was removed from the bench-perhaps seven in all-some of which escaped press attention. ${ }^{37}$

For instance, on January 24, 1925, Norris left for another several months-long-trip around the world on the RMS Homeric, ${ }^{38}$ advertised as a "ship of splendor" with the "highest value in equipment, service and cuisine, that can be offered." 39 The itinerary included stops in Great Britain, France, Spain, Italy, Turkey, Greece, and Morocco, with a return date nine weeks later on April 1, 1925. ${ }^{40}$ Here, again, this trip was characterized over the years as one involving the study of prostitution enforcement in Europe. ${ }^{41}$ But Norris's 1924 passport application for the Homeric cruise indicates it was a "pleasure" trip. ${ }^{42}$

Norris's 1924 passport application-compared to other travel documents - raises other questions, too. For example, although her stated date of birth on the 1924 application is January 25, 1877 matches the date provided on her 1922 application for the Samaria cruise $^{44}$ - her 1904 passport application lists her birthdate as January 25,

35. Id.; see also 'Joyriders' De Luxe and Giant Liner Taking Them Around World, HonOLULU StAR-Bull., May 7, 1923, at 4.

36. Judge Jean Norris Honored in Orient, N.Y. TimeS, May 27, 1923, at 6 (Norris said the most exciting part of her trip was being placed under heavy guard during her travels from Canton to Shanghai, to be protected from bandits who had swarmed an earlier train and took hostages).

37. See, e.g., Manifest Documents, San Lorenzo Cruise Ship (Mar. 25, 1924); Manifest Documents, Homeric Cruise Ship (Apr. 1, 1925); Manifest Documents, Ulua Cruise Ship (June 19, 1927); Manifest Documents, Franconia Cruise Ship (May 31, 1928); Manifest Documents, Sixaola Cruise Ship (Oct. 4, 1928); Manifest Documents, Île de France Cruise Ship (July 23, 1929); Manifest Documents, Havana Cruise Ship (Mar. 14, 1930) (all on file with author).

38. See U.S. Passport Application, Jean H. Norris (Dec. 23, 1924) [hereinafter 1924 Passport Application] (on file with author).

39. See Advertisement, Thos. Cook \& Son: Mediterranean, the Cruise Supreme 1925 on the Homeric, N.Y. HERALD, Dec. 9, 1924, at 5.

40. 1924 Passport Application, supra note 38.

41. See, e.g., Jean Norris Plays Traitor to Girls Trapped by Sex, DAILY NEWs, Feb. 15, 1931, at 76 (cataloging Norris's many international trips and noting Norris had studied "the scarlet woman problem ... in almost every country in Europe").

42. 1924 Passport Application, supra note 38; see also Manifest Documents, Homeric, supra note 37.

43. 1924 Passport Application, supra note 38.

44. 1922 Passport Application, supra note 28. 
$1876 .{ }^{45}$ A single error like this might be chalked off as an oversight. But after her Homeric cruise, Norris's date of birth changed again. For the next four vacations she provided a date of birth of January $25,1878 .{ }^{46}$ But in 1930, shortly before she was removed from the bench, Norris got younger yet as she boarded another cruise ship — with a listed date of birth of January $25,1879 .{ }^{47}$

Here, again, these might be viewed as simple human mistakes - or somewhat endearing efforts of an aging woman to resist the effects of time. But when considered in context - including Walker's vacations funded by third parties seeking favors, in addition to serving as a means of moving illegal graft - they might suggest a constructed front on her part to cover something that was less than innocent. Or they may demonstrate looseness with the truth.

Indeed, upon her return from an East African cruise in 1928, Norris regaled reporters with stories of being successful on her first safari, holding up a tiger pelt she earned as a trophy. ${ }^{48}$ Whether or not her hunting acumen could be believed - including taking down a long-horned antelope on her third shot - what is credible is that she did not bring back the pelt for family or friends. ${ }^{49}$ Instead, as she told the press, it was for "Tammany Leader George W. Olvany." 50

In 1929, Norris was again a guest on the luxurious Homeric liner. This time it was for a dinner at the dock for the influential social group, the Amen Boys, which historically limited its membership to older white men. ${ }^{51}$ For the event, Norris reported wearing a remarkable " $\$ 5,000$ diamond brooch" that ultimately_or perhaps supposedly—went missing, resulting in police investigation. ${ }^{52}$ Apparently her jewels were never found..$^{53}$ And the next year, just a few months before she was removed from the bench, Norris departed on yet another month-long cruise, this

45. U.S. Passport Application, Jean H. Norris (Dec. 23, 1904) (on file with author).

46. Manifest Documents, Homeric, supra note 37; Manifest Documents, Ulua, supra note 37; Manifest Documents, Franconia, supra note 37; Manifest Documents, Sixaola, supra note 37; Manifest Documents, Île de France, supra note 37.

47. Manifest Documents, Havana, supra note 37.

48. Brings Home Tiger Pelt, BrooK. DaIly EAGLE, June 1, 1928, at 19.

49. $I d$.

50. Id.

51. Guide to the Grand Street Boys' Association Records, AM. JEWISH HIST. SoC'Y, http://digifindingaids.cjh.org/?pID=109157 (last visited Oct. 1, 2019) (describing the Amen Boys as the arm of the Grand Street Boys Association dedicated to older group members, a group that included such notables as Al Smith and members of the Rockefeller family).

52. Magistrate Norris Loses \$5,000 Gem; Hunt on Liner Fails, BroOK. DAILY EAGLE, Sept. 27, 1929 , at 29.

53. Magistrate Norris Seeks $\$ 5,000$ Brooch, BROOK. Times UniON, Sept. 27, 1929, at 41 (stating that Norris was still looking for her brooch the day after it had been lost to no avail). 
time to Mexico. ${ }^{54}$ The press noted, without making any further connections, that Olvany just happened to leave on his own luxury cruise the very same day. ${ }^{55}$

\section{TRAGEDIES AND SECRETS}

These trips were not the only times in her life that Norris made conflicting claims about her age. Over time she apparently offered different representations about when she had become a widowsometimes saying it was at age twenty while at other times age twentytwo. ${ }^{56}$ Once coupled with other circumstances around the death of Norris's husband, this, too, may have raised questions of interest to Seabury and others - at least by today's standards. On the one hand, the story of her marriage and its conclusion serves as mitigating evidence relating to early life struggles and traumas; on the other, it could be read as raising the specter of true callousness or more serious wrongdoing on her part. Either way, it allows us to understand Norris and her life as being more complex than beginning and ending with her removal from the bench.

Whenever Mrs. Jean Hortense Norris was interviewed about her marriage, she simply said she had become a widow unexpectedly at a young age. ${ }^{57}$ She almost never mentioned her husband's name nor the circumstances surrounding his death.

But in 1897 Jean Hortense Norris, who went by the name Jennie Noonan in her younger years, married Thomas H. Norris of Brooklyn, a man nearly twice her age. ${ }^{58}$ Although it is unclear when they first met, it seems likely the courtship was arranged as part of political maneuvering among the men of Brooklyn's Republican Party while Jean was still a teen. In July 1894 the budding relationship was hinted at by the Brooklyn Daily

54. Olvany Sailing Today for Trip to West Coast, BrooK. Daily EAGLE, Feb. 8, 1930, at 7.

55. Id.

56. See The Revolver Was Loaded, supra note 8, at 16 (stating her age as twenty); Espenscheid, supra note 9 , at 3 (stating her age as twenty-two).

57. See, e.g., Mrs. Norris, On Bench, Sees Flotsam of Woman's Court; Wears String of Pearls, BrooK. Daily EAgLe, Oct. 28, 1919, at 1 [hereinafter Mrs. Norris, On Bench] (noting that Mr. Norris died about twelve years ago as of the time of the article); Espenscheid, supra note 9, at 74 (quoting Norris: "I was 20 when I married ... and 22 when Mr. Norris died." (internal quotation marks omitted); Woman Lawyer Writes on the Trial of Christ, BROOK. DAILY EAGLE, Mar. 10, 1914, at 22 (quoting Norris: "My husband died when I was very young and being left absolutely without any means of support I took up secretarial work.").

58. About Brooklyn People, Brook. DAIly EAgLe, July 29, 1894, at 9. See The Revolver Was Loaded, supra note 8, at 16; see also WOMAN's WHO's WHO OF AMERICA: A BIOGRAPHICAL DICTIONARY OF CONTEMPORARY WOMEN OF THE UNITED STATES AND CANADA, 1914-1915, at 601 (John William Leonard ed., 1914) [hereinafter WOMAN's WHO's WHO OF AMERICA] (entry for Jean Hortense Norris). 
Eagle. ${ }^{59}$ It reported that Miss Jennie Noonan, who at the time was no older than seventeen years of age, would be vacationing at Lake Bomoseen, Vermont with Mr. Thomas Norris, in his mid-thirties. ${ }^{60}$ They were accompanied by two married women chaperones; one was the wife of one William J. Buttling. ${ }^{61}$

Buttling happened to be a sheriff and powerful Republican Party boss in Brooklyn who was known for his temper, ruling with an iron fist, and taking care of things. ${ }^{62}$

Jean Norris's father, John Giles Noonan, a retired Civil War Veteran, was also involved in local Republican politics. ${ }^{63} \mathrm{He}$, too, was accused of financial wrongdoing while serving in a local leadership role for the party. ${ }^{64}$ He further served as the warden of the Raymond Street Jail in Fort Greene directly under Buttling. ${ }^{65}$ Thomas Norris, whose family also appeared to be Buttling Republican loyalists, was apparently allowed the privilege to pursue Noonan's daughter. ${ }^{66}$

Thomas and Jennie's relationship continued for several years, with the Brooklyn Eagle again noting their joint attendance at the Brooklyn Academy of Music in February 1897 for a Volunteer Firefighters' fundraiser. ${ }^{67}$ The two finally wed, according to Jean Norris's report to the publishers of the 1914-1915 Woman's Who's Who of America, on June 30 of $1897 .{ }^{68}$ She would have been twenty years old, if that, while Thomas was thirty-eight.

59. About Brooklyn People, supra note 58, at 9.

60. $I d$.

61. Id. (noting Mrs. William J. Buttling and her two children joined Noonan and Norris in Vermont, along with a Mrs. John Hazelton).

62. Buttling Attacks Dady, N.Y. DAILY TRIB., July 30, 1899, at 3 (reporting on Buttling's violent outburst at a local Board of Elections office); Buttling Causes a Disturbance in the Second District Convention, BROOK. DAILY EAGLE, Apr. 3, 1900, at 7 (describing Buttling as having a reputation for ruling Republican party conventions with "an iron hand").

63. Mrs. Norris, On Bench, supra note 57, at 1; To Instruct Voters, The Republican Committee Takes its First Step, BrooK. DAILy EAGLE, July 29, 1890, at 1 (noting John G. Noonan's attendance at a Republican Club meeting to discuss a new ballot system).

64. Fifth Ward Republicans Will Make an Assault on the Navy Yard Patronage, BroOK. DAILY EAGLE, Jan. 22, 1890, at 1 (noting that Norris's father addressed concerns about "fraud or bribery" of Republican Party members and explained that the unknown sums of money were provided to cover various costs incurred).

65. Mrs. Norris, On Bench, supra note 57, at 1.

66. See Worth Cohorts in Albany, BROOK. DAILy EAgLE, April 25, 1895, at 16 (listing Thomas H. Norris as among those Republicans who traveled to Albany to support the reorganization of the state's Charities Agency); Obituary, Died, Brook. DAily EAGLE, May 10, 1899, at 9 (referencing Thomas H. Norris as among the Club brothers in an obituary announcement); Knights of Columbus Dine, BROOK. DAILY EAGLE, Jan. 24, 1911, at 8 (reporting that Buttling, along with members of the McCluskey family, made remarks at the John Loughlin Council annual dinner).

67. An Old Firemen's Night, BrooK. DAILy EAGLE, Feb. 2, 1897, at 11.

68. WOMAN's WHO'S WHO OF AMERICA, supra note 58, at 601. 
The childless couple apparently lived on the second-floor of a threestory walk up in the Bedford-Stuyvesant area of Brooklyn. ${ }^{69}$ Thomas, a member of the Knights of Columbus, ${ }^{70}$ worked as a traveling salesman for Valentine and Company of Manhattan, ${ }^{71}$ a group that manufactured automobile and train varnish. ${ }^{72}$ Given norms of the day, it would make sense that Norris stayed home and helped care for Thomas's invalid mother, who lived with the couple. ${ }^{73}$ Thomas had his own medical problems, too, as a long-time diabetic who reportedly had vision problems and possibly suffered from depression. ${ }^{74}$ Thus, young Norris did not enjoy an easy life as a married woman, and joy would have been in short supply.

Although there were plenty of opportunities for her to do so over the years, Jean Norris never offered public statements about love lost with Thomas's death. Rather, in interview after interview about her views on marriage, she offered what might be viewed as antiseptic assessments of the institution - which were at once traditional and cynical. For instance, at times she suggested that marriage was an important and sacred commitment that was too easily dissolved by way of divorce. ${ }^{75}$ But she also noted that in the past wives were unfairly prevented from having their own careers or financial independence, ${ }^{76}$ and girls wed at too young an age, ${ }^{77}$ frequently resulting in the "mating of misfits" where love "curdled to hate" and "bitterness.", 78

While a judge, Norris further admitted that cases involving marital disputes caused her "nervous depletion and depression" and were more difficult than any other that she handled. ${ }^{79}$ She found domestic violence matters among the most troubling, particularly since so many battered women begged for their abusers to come home - even after Norris sent

69. The Revolver Was Loaded, supra note 8, at 16 (reporting that the Norrises lived in the "second flat at 985 Lafayette [A]venue" in Brooklyn).

70. See Obituary, Died, supra note 66, at 9.

71. The Revolver Was Loaded, supra note 8, at 16.

72. See, e.g., Advertisement, Valentine's Valspar Enamel: Stuck in the Mud for 13 Days-but Valspar-Enamel Sees it Through!, SATURDAY EvENING Post, at 59 (Aug. 26, 1925), http://www.virtu alsteamcarmuseum.org/makers/valentine_and_company.html [https://perma.cc/UXE2-Y9S2].

73. The Revolver Was Loaded, supra note 8, at 16.

74. $I d$.

75. See Jean H. Norris, The Marriage Problem, AtLanta ConST., Mar. 1, 1927, at 8 (on file with author) (referring to "appalling divorce statistics" that show wedding vows now mean little and hoping that "America will regain her original wholesome outlook on the question of marriage").

76. See Norris, Judging Women, supra note 11, at 23.

77. See Martha Coman, Few Early Marriages; Each Year Shows Age Jump, N.Y. Herald, Apr. 24,1921 , at 80 .

78. See Jean Hortense Norris, Why Some Husbands and Wives Quarrel, 92 AM. MAG. 34, 34 (1921).

79. Id. 
them to jail to protect the women. ${ }^{80}$ She further blamed clergymen who were allowed to end their responsibilities to such couples "with the mere performance of the marriage ceremony" without taking "a genuine interest in the health and future happiness of the bride and groom." 81 Throughout all of this, although quick to note her family of origin was a respectable lot who had been in the United States for six generations, ${ }^{82}$ she never reminisced about her deceased husband or claimed to be grieving his death.

But on May 8, 1899, when police found her husband dead in their apartment with a bullet through the back of his head, she reported that he had seemed "somewhat despondent" as of late. ${ }^{83}$ But she also claimed he was playful that evening, putting the muzzle of the gun in his own mouth as a kind of game. ${ }^{84}$ Jean Norris, described by the press at that time as "a remarkably pretty young woman," offered other details about Thomas's death that could be read as being in conflict, too. ${ }^{85}$

On the one hand, she told police that Thomas had unloaded the gun first, cartridge by cartridge, even showing her the chamber to prove it was empty, before he pulled the trigger while still looking at her. ${ }^{86}$ Given his diabetes and poor eye sight, she offered, he must not have seen that the gun was still loaded. ${ }^{87}$ On the other hand, Jean also reported that she retired to bed that night, leaving Thomas on the couch to sleep, and "raised an alarm" as "soon as [she] realized what had happened to her husband." Other press accounts quote Norris as indicating the shooting occurred while Thomas was resting on a lounge chair in her presence. ${ }^{89}$ Yet another news story reported that Norris was sitting in the dining room with Thomas, when he accidentally shot himself. ${ }^{90}$

In terms of her "rais[ing] an alarm" to report the incident, one report indicates Norris immediately ran from the apartment and notified an officer from the Ralph Avenue Police Station, who in turn contacted an

80. Id. at 34, 102-03.

81. Norris, The Marriage Problem, supra note 75 , at 8.

82. See Norris, Why Some Husbands and Wives Quarrel, supra note 78, at 35 ("Judge Norris comes of an old New York Family, both branches having lived there for six generations.").

83. The Revolver Was Loaded, supra note 8, at 16.

84. Id.

85. Played with a Loaded Pistol, Brook. Citizen, May 9, 1899, at 1.

86. The Revolver Was Loaded, supra note 8, at 16.

87. Id.

88. Id.

89. Played with a Loaded Pistol, supra note 85, at 14.

90. Killed in Cleaning Pistol, STANDARD Union, May 9, 1899, at 3. 
ambulance. $^{91}$ But another article suggests neighbors were the ones who summoned police to the scene from the Gates Avenue police precinct. ${ }^{92}$

For whatever reason, the officer ultimately assigned to the case, Detective John McCloskey, apparently did not undertake the kind of probing investigation he used in other questionable suicide cases. ${ }^{93}$ Instead McCloskey, who in an uncanny turn of events took his own life thirty-six years later by way of gunshot "through the mouth," promptly closed the matter. ${ }^{94}$ No family funeral service was noted in the Brooklyn Daily Eagle, as was the usual practice. Instead the paper shared word of a memorial held for Thomas by his Knights of Columbus brethren. ${ }^{95}$

It is unclear what became of Mrs. Jean Norris's invalid mother-in-law. But shortly after Thomas's death, the contents of the couple's apartment were put up for sale. An ad in the Brooklyn Daily Eagle sought purchasers for all the belongings less than three weeks after Thomas died. ${ }^{96}$

Jean Norris moved to a brownstone owned by three sisters on Brooklyn's Nostrand Avenue, who rented rooms to boarders-including several other families. ${ }^{97}$ And yet in October 1900, little more than a year after her husband's death, she somehow managed to become seated at the "right hand" of Lieutenant Governor Woodruff and other Republican Party leaders. ${ }^{98}$ According to a single obscure reference in the Brooklyn Daily Eagle, which includes a drawing of young Norris working closely with Republican Party leader Clarence Barrow, ${ }^{99}$ Norris had become Woodruff's "private stenographer." 100 She was further described as being "trusted with more secrets than falls to the lot of the majority of the

91. The Revolver Was Loaded, supra note 8, at 16 (reporting that Norris "raised an alarm"); Played with a Loaded Pistol, supra note 85, at 16 (reporting that Norris immediately ran out of the apartment and notified an officer). The Ralph Avenue Police Station no longer exists in Brooklyn.

92. The Revolver Was Loaded, supra note 8, at 16.

93. Id. (reporting that Detective McCloskey arrived on the scene shortly after Mr. Norris's death). See Magee Sticks to His Story, BROOK. DAILY EAgLE, Mar. 19, 1894, at 12 (reporting on McCloskey's dogged "probe" leading to an inquest around the "mystery" of a local woman, asking "was it murder or was it suicide"); see also Frank Wilson, McCloskey's District Has Run of Unsolved Murders Since Slaying of Florence Kane, BROOK. DAILY EAGLE, Oct. 17, 1926, at 81 (noting that "McCloskey's Murder District" had half a dozen unsolved murders in the past two years).

94. Inspector's Rites for McCloskey, Police 'Iron Man,' BrooK. Daily EAgLe, Nov. 23, 1935, at 11 .

95. Obituary, Died, supra note 66.

96. For Sale-Furnishings of a Flat, BRoOK. DAILY EAGLE, May 24, 1899, at 10 (advertising that all of 985 Lafayette Avenue, second flat, was for sale in "whole or part").

97. See New York State Census 1905, CENSUS BUREAU RECORDS (on file with author).

98. Snap Shots Taken at Local Political Headquarters, BrooK. DAILY EAGLE, Oct. 21, 1900, at

6.

99. See, e.g., id.

100. Id. 
politicians who frequent [the Republican Party] headquarters."101

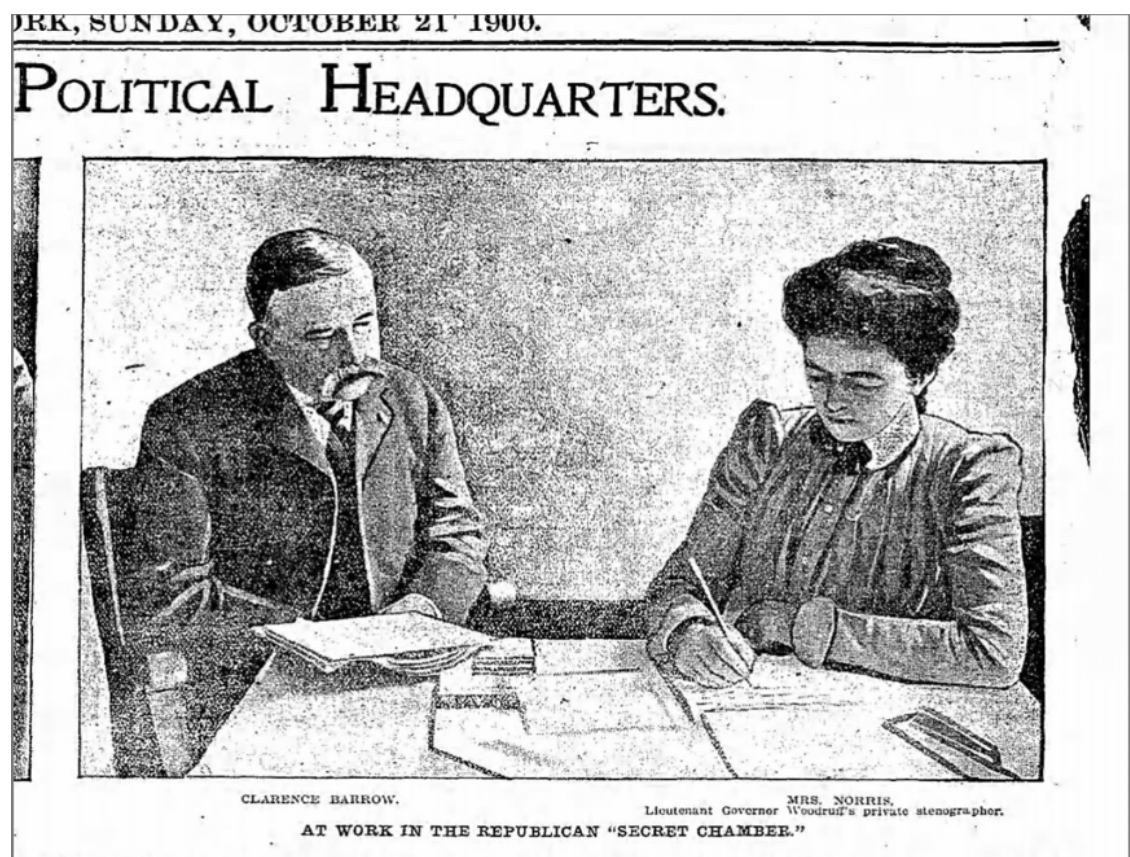

These secrets - and likely many others about her life, legal career, and judgeship - were carried by Mrs. Jean Hortense Norris to her death, which occurred on September 7, $1955^{102}$ without prominent mention in the papers. Records reflect she was interred at Holy Cross Cemetery in Brooklyn, joining her Republican father who was laid to rest in $1894 .{ }^{103}$ And somewhat surprisingly given her life-long honorific as "Mrs." Jean Hortense Norris, it appears she was not buried with her husband Thomas. Holy Cross Cemetery does not have a gravesite for a Thomas H. Norris who died at age forty. However, there is such a grave across town at Calvary Cemetery. ${ }^{104}$ Assuming this is Judge Norris's deceased spouse, he was apparently permitted a Roman Catholic burial despite the thenexisting religious ban on such privileges for persons who took their own

101. Id.

102. See Locate a Loved One, CATH. CEMETERIES BROOK., https://www.ccbklyn.org/informationnews/locate-a-loved-one/ [https://perma.cc/5E6A-HGD3] (last visited Oct. 1, 2019) (select "Holy Cross Cemetery - Brooklyn" and enter "Norris" in "Last Name" field and "Jean" in "First Name" field).

103. See id. Telephone Interview with Holy Cross Cemetery staff (Nov. 13, 2019) (confirming that Jean Norris was buried next to her father, John G. Noonan, in Holy Cross Cemetery).

104. Telephone Interview with Calvary Cemetery staff (Nov. 13, 2019) (stating that a Thomas H. Norris, aged forty at the time of death, was buried at Calvary Cemetery on May 11, 1899). 
lives. ${ }^{105}$

\section{CONCLUSION}

Jean Hortense Norris continues to present a complicated picture for legal historians and others. Many of her fellow students at New York University may have been taken aback by her arrival in the early 1900s to seek a law degree at such a late age, her relatively quick rise to power in the Democratic Party as the state's first female jurist, and then her prominent public disgrace in being removed from the bench.

But those who knew Jennie Noonan in her early years - as she wed the man twice her age while likely just a teen, became a struggling widow in her twenties, and then somehow was near-immediately elevated to serve as confidante to some of the most powerful Republican men in New York - might not have been so stunned. Those same people also may not have been very surprised to hear about her ever-changing stated age, expensive world travels, and extravagant jewelry, even while a public servant receiving city employee wages. Her claim of taking down a target — possibly a threat — with a carefully placed shot might not have seemed so out of character for those closest to Norris, either.

In the end we may never know all there is to know about Jean Hortense Norris, particularly regarding her finances, travels, and the circumstances surrounding her early widowhood. Like the feminist shirt waists she wore throughout her life, Norris was versatile and presented herself differently across forums. Not just fallen a woman, she was more than her worst acts alone. And though more than just an innocent victim, Norris may have crossed more than one line during her life. Like all of us, Norris enjoyed a complicated existence, one that probably could not be wholly forecast in advance. With each additional excavation effort, we may find more pieces, add to the picture, and suggest yet more (re)framing. Still, complete knowledge of Jean Hortense Norris will remain elusive, tensions in her life story unresolved, and long-buried potential misdeeds unsolved.

105. James Stuart, Funerals Due to Suicide \& the Roman Catholic Church, ClassRoom ONLINE (Sept. 29, 2017), https://classroom.synonym.com/funerals-due-to-suicide-the-roman-catholic-church12085229.html [https://perma.cc/4PSR-SHYQ] (reporting on the historic ban on Catholic funerals and burials in cases of suicide, which was lifted in 1983). 